\title{
Medicinal Vessels from Tell Atrib (Egypt)
}

\author{
Adam Łajtar, Anna PoludniKiewicz
}

\begin{abstract}
This article offers publication of seventeen miniature vessels discovered in Hellenistic strata of Athribis (modern Tell Atrib) during excavations carried out by Polish-Egyptian Mission in the 1980s/1990s. The vessels, made of clay, faience and bronze, are mostly imports from various areas within the Mediterranean, including Sicily and Lycia, and more rarely - local imitations of imported forms. Two vessels carry stamps with Greek inscriptions, indicating that they were containers for lykion, a medicine extracted from the plant of the same name, highly esteemed in antiquity. The vessels may be connected with a healing activity practised within the Hellenistic bath complex.
\end{abstract}

Keywords: Tell Atrib, Hellenistic Egypt, pottery, medicinal vessels, lykion, healing activity

Adam Łajtar, Institute of Archaeology, University of Warsaw, Warszawa; a.lajtar@uw.edu.pl

Anna Południkiewicz, Polish Centre of Mediterranean Archaeology, University of Warsaw, Warszawa; poludnik@yahoo.com

Archaeological excavations carried out between 1985 and 1999 by a Polish-Egyptian Mission within the Hellenistic and Roman dwelling districts and industrial quarters of ancient Athribis (modern Tell Atrib), the capital of the tenth Lower Egyptian nome, ${ }^{1}$ yielded an interesting series of miniature vessels made of clay, faience and bronze. ${ }^{2}$ Identical or similar vessels are known from numerous sites within the Mediterranean and are considered as containers for medicines in a liquid form.

A particularly rich collection of such vessels, amounting to 54 objects, was discovered in the 1950s, during work carried out by an American archaeological expedition in Morgantina

\footnotetext{
${ }^{1}$ For a preliminary presentation of the results, see reports published in journal Polish Archaeology in the Mediterranean (vols I-VII, by K. Myśliwiec; vols X-XI, by H. Szymańska); for a summary of the results, see: Myśliwiec 2000a; 2009; see also: 2011.

${ }^{2}$ Anna Południkiewicz is responsible for the archaeological side of the paper and Adam Lajtar for the epigraphic one.
} 
on Sicily. The vessels, mostly of local production, were published by Erik Sjöqvist, ${ }^{3}$ who dated them contextually to the third/second century $\mathrm{BC}$ and divided them into six types (1-6) based on formal criteria.

Another collection of such objects consisting of twenty-five items originating from various sites in Palestine and dating from the Hellenistic through to the Roman Imperial periods was published by Malka Hershkovitz. ${ }^{4}$ She divided the vessels into four types (A-D), of which the first and the second consisted of imported objects, whereas the third and the fourth represented local production.

Based on the finds from Morgantina and Palestine, but also on individual objects of various proveniences, Luigi Taborelli and Sylvia Maria Marengo then attempted an overview of the entire material..$^{5}$ They distinguished four groups (rather than types) in this material: A - Sicilian, B - South-Italian, C - Athenian or central Mediterranean, and D - Oriental Mediterranean.

Recently, Gül Işin, posited a new typology of these vessels while working on the material excavated in Patara in Lycia. ${ }^{6}$ She was able to distinguish six types:

- Type I (Athenian agora): handleless bottles, mostly plump, pear-shaped provided with a raised base and having a flaring or vertical profile, or else bottles with a flat bottom, slightly concave on the underside. String marks are usually visible on their undersides and most are glazed both inside and outside;

- Type II (Morgantina): heavy pear-shaped jars with a concave neck and somewhat flaring rim, mostly provided with a raised flat base. The majority of these examples have two handles placed either vertically or horizontally;

- Type III (Eastern type, Patara): vessels with a biconic body, with an irregular or a regular profile, a wide mouth, and rim ranging from vertical to everted. This type also features a flaring or vertical, sometimes raised, base usually with string marks at the bottom. Sometimes the upper body and the interior of the mouth are covered with reddish or black paint by a dipping technique. The heights of such vessels ranges between 4 and $5 \mathrm{~cm}$;

- Type IV (Jerusalem-Masada-Samaria, Tell Anafa, and Jaffa): miniature cups with a flaring rim, squat globular body, high flat base and a thin vertical handle reaching from rim to mid-point on the body. The fabric is buff to pink and most examples have brownish red paint around the rim and shoulder. The height ranges between 3 and $5 \mathrm{~cm}$;

- Type V (Athenian agora; Louvre): vessels representing mixtures of Type I and Type IV, with pear-shaped body and one handle; the handle reminds one of the miniature types of an olpe;

- Type VI (Priene): relatively high jars (around $10 \mathrm{~cm}$ ), with a slightly raised ring base, a cylindrical body, getting narrower through to the lip.

\footnotetext{
${ }^{3}$ Sjöqvist 1960; see also: Stone 2014: 111-113.

${ }^{4}$ Hershkovitz 1986.

${ }^{5}$ Taborelli, Marengo 1998; 2010.

${ }^{6}$ Işin 2002.
} 
Since none of these typologies is fully applicable for the material from Tell Atrib (not to mention that they seem partly contradictory), the authors of the present paper refrain from giving their own typology. However, while presenting individual vessels from the site references to existing typologies will be given.

\section{CATALOGUE}

\section{Miniature AND SMALl HANDLELESS CUPS, CAT. NOS 1-9 (Figs 1-3, 9a-h)}

The vessels cat. nos 1-4 represent Sjöqvist type 3, and Hershkovitz type A. These are miniature handleless cups with a raised flat base, bulging body, straight walls, slightly narrowing toward the top, and a slightly out-turned rim. They were imported to Tell Atrib, possibly from Asia Minor or Palestine. ${ }^{7}$ The vessels cat. nos 5-7 are local imitations of the above-mentioned form. ${ }^{8}$ Vessels cat. nos 8-9 are - in terms of morphology - similar to cat. nos $1-4$, but two times larger.

\section{TA $91 A / 19$ (Figs 1:1, 9a)}

Archaeological context: square PP, ${ }^{9} 0.7 \mathrm{~m}$ from the west border of the square, $2.4 \mathrm{~m}$ from its north border, between rooms 136 and $186,0.8 \mathrm{~m}$ below the top of the walls of room 186 ; early-Ptolemaic district of artisan workshops, in a layer with traces of burning containing a large amount of pottery.

H. $2 \mathrm{~cm}$, W. $1.9 \mathrm{~cm}$.

Light brown clay, well silted, surface with black slip, matt.

An almost completely obliterated impression of a rectangular $(0.8 \times 0.4 \mathrm{~cm})$ stamp with two(?) lines of Greek inscription visible on the lower part of the body and on the base.

\section{TA 93/75P (Figs 1:2, 9b)}

Archaeological context: square GGG, north-east corner of the room 222, $2.2 \mathrm{~m}$ below the surface; early-Ptolemaic district of artisan workshops.

\section{H. $2.3 \mathrm{~cm}$, W. $2 \mathrm{~cm}$.}

Very well levigated clay, fine, light brown (2.5YR 4/6), with many lime inclusions and a few pieces of mica. On the exterior surface, a dark orange slip (2.5YR 5/6), slightly polished.

\footnotetext{
${ }^{7}$ Myśliwiec 2000b: 258.

${ }^{8}$ Imported Greek pottery was frequently imitated in Ptolemaic Egypt. Generally on this subject, see: Południkiewicz 1992.

${ }^{9}$ For the grid applied during excavations at Tell Atrib, see: Myśliwiec 2000a: 14, Fig. 3.
} 

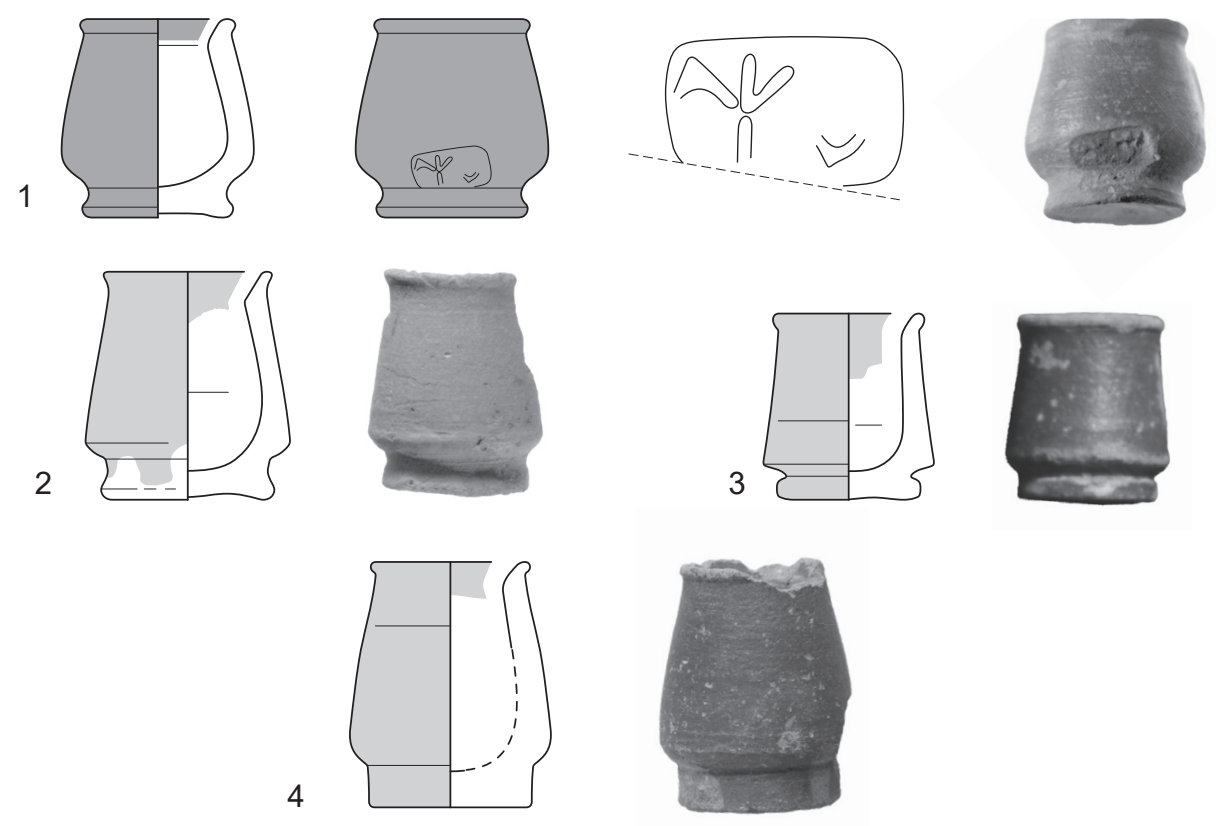

0

$5 \mathrm{~cm}$

1. Pottery miniature vessels (cat. nos 1-4) from Tell Atrib (Drawing: P. Mieliwodzki, A. Południkiewicz; digitizing: M. Momot; Phot. W. Jerke, A. Południkiewicz).

\section{TA 94/91 (Figs 1:3, 9c)}

Archaeological context: south-east part of the square CCC, $1.6 \mathrm{~m}$ from the southern border of the square, $5.0 \mathrm{~m}$ from its west border, $0.8 \mathrm{~m}$ below the top of a wall running in south-north direction; public bath of mid-Ptolemaic period (time of Ptolemy VI and later). ${ }^{10}$

H. $2 \mathrm{~cm}, W .1 .6 \mathrm{~cm}$.

Fine, brown clay (10R6/4), red slip on the surface (2.5YR 5/6).

\section{TA 91A/WITHOUT INVENTORY NUMBER (Figs 1:4, 9d)}

Archaeological context: unknown. As the object came to light during the 1991 excavation season it must have originated in the Ptolemaic strata, in the north-western part of the excavated area, either within the bath complex or in the industrial quarter.

H. $2.5 \mathrm{~cm}$, W. $2 \mathrm{~cm}$.

\footnotetext{
${ }^{10}$ For the bath, see: Myśliwiec 1998; 2000a: 33-35.
} 

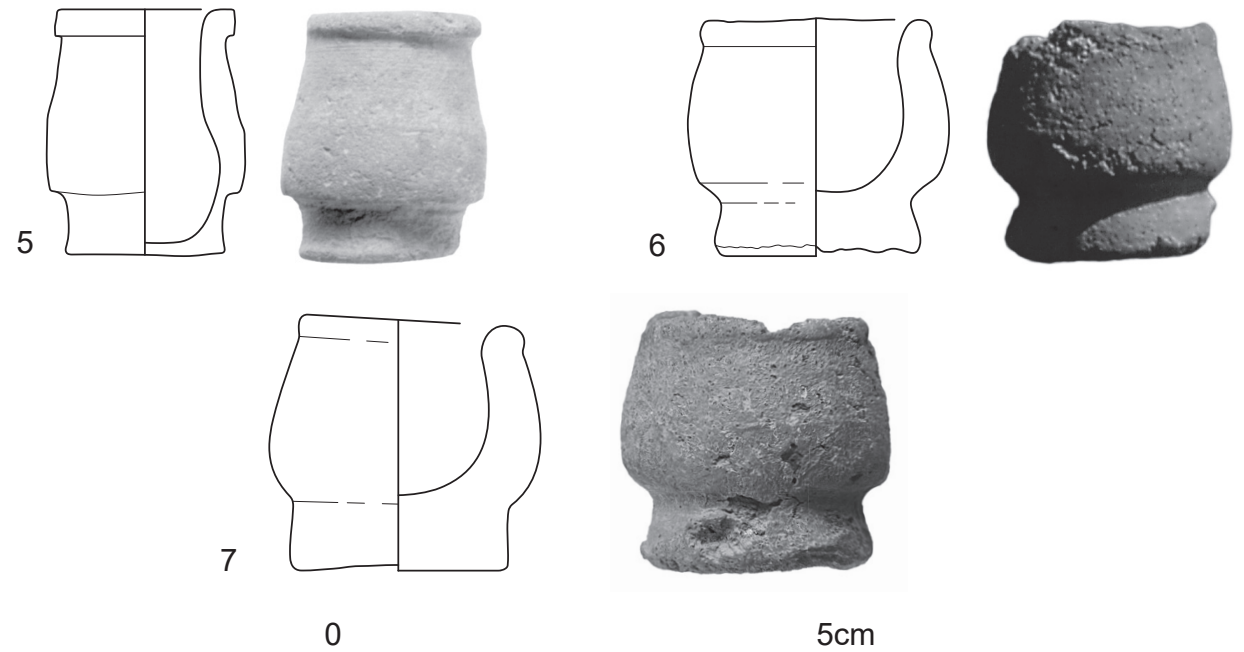

$5 \mathrm{~cm}$

2. Pottery miniature vessels (cat. nos 5-7) from Tell Atrib (Drawing: P. Mieliwodzki, A. Południkiewicz, M. Momot; digitizing: M. Momot; Phot. W. Jerke, K. Myśliwiec).

Pinkish, light beige clay (5YR 6/3), with inclusions of mica and lime particles. Orange slip (5YR 4/6), slightly polished, covering inside of the rim and edge of the underside of the foot. Two spots without a slip on the foot may reflect the way the vessel was held while the slip was put on the surface.

\section{TA 90/8P (Fig. 2:5)}

Archaeological context: south part of the room 159B, ${ }^{11} 1.5 \mathrm{~m}$ from the south wall, $0.1 \mathrm{~m}$ from the east wall, $0.2 \mathrm{~m}$ below the top of the east wall; public bath of mid-Ptolemaic period (time of Ptolemy VI and later).

\section{H. $2.5 \mathrm{~cm}$, W. $2 \mathrm{~cm}$.}

Nile silt, porous, with some inclusions of mica, sand and lime.

\section{6. $T A$ 95/107P (Figs 2:6, 9e)}

Archaeological context: square XX, $2.5 \mathrm{~m}$ from the northern border of the square, $2.6 \mathrm{~m}$ from its eastern border, $1.7 \mathrm{~m}$ below the top of a wall in the neighbouring square $\mathrm{ZZ}$; public bath of mid-Ptolemaic period (time of Ptolemy VI and later).

\section{H. $2.5 \mathrm{~cm}$, W. $3 \mathrm{~cm}$.}

\footnotetext{
${ }^{11}$ For room 159, see: Myśliwiec 2000a: 35-37. This relatively small room, located in the middle of the bath complex, must have had an important function within the bath, as suggested by its decoration and contents. According to Karol Myśliwiec it might have been a place of ritual celebrations in honour of Dionysos.
} 

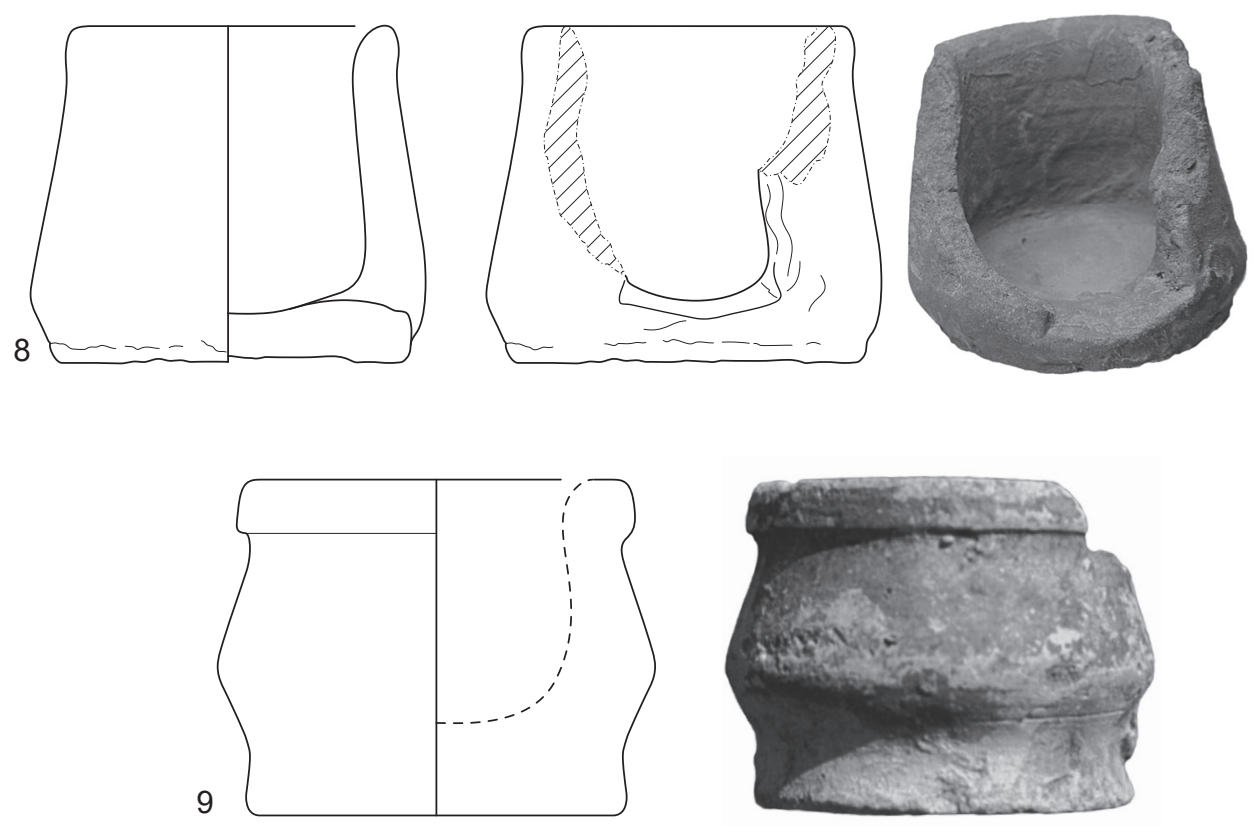

0 $5 \mathrm{~cm}$

3. Pottery miniature vessels (cat. nos 8-9) from Tell Atrib (Drawing: P. Mieliwodzki, M. Momot; digitizing: M. Momot, M. Puszkarski; Phot. W. Jerke, A. Południkiewicz).

Nile silt, porous, brown (7.5R6/4), many inclusions, some mica.

\section{TA 90/WITHOUT INVENTORY NUMBER (Figs 2:7, 9f)}

Archaeological context: unknown. Since the object was discovered during the 1990 season it must have come from the Hellenistic strata.

\section{H. $2.6 \mathrm{~cm}$, W. $2.7 \mathrm{~cm}$ (irregular).}

Nile silt, porous, dark orange (10R 5/6), some lime inclusions. On the exterior surface traces of an orange slip and self slip. Inside of the pot there is a fracture resulting from the firing of the vessel.

\section{TA 95/122P (Figs 3:8, 9g)}

Archaeological context: square JJJ, room $223,0.4-0.6 \mathrm{~m}$ below the top of the wall separating room 223 and room 224; early-Ptolemaic artisan quarter, in a layer of brown earth with large amounts of pottery.

H. $3.4 \mathrm{~cm}$, W. $4 \mathrm{~cm}$. 
Nile silt, well-levigated, light brown, self slip.

The remains of an opening through the wall made before firing is visible near the bottom. Its exact shape cannot be determined since the vessel is incomplete. The presence of the opening raise the question as to whether the vessel could have functioned as a container for medicines. It was included in the catalogue because of its miniature dimensions and its typological similarity with medicinal vessels.

\section{TA 94P/A53 (Figs 3:9, 9h)}

Archaeological context: square CCC, room 237, 0.7-0.8m below the top of the northern wall of the room; mid-Ptolemaic period; several coins of Ptolemy VI were found in the same context.

\section{H. $3.4 \mathrm{~cm}$, W. $4.5 \mathrm{~cm}$; Rim dia. $4 \mathrm{~cm}$.}

Light pink (5YR 5/3), slightly porous clay with a few lime particles and sand. Red slip (2.5YR 5/6), covering irregularly the external surface on the upper half of the vessel. Some marks visible on the lower part of the object. The clay and the fabric suggest it is an import.

\section{Miniature tall Vessels, CAT. nOS 10-11 (Figs 4, 9i-j)}

The vessels cat. nos 10-11 resemble Sjöqvist type 4. In terms of form, these are similar to those described above (Sjöquist type 3) but much taller. Similarly tall vessels were found on several sites in the Aegean, including Corinth, Athens, and Delos. ${ }^{12}$ Some scholars have suggested their use as pigment containers but, most probably, similarly as other miniature vessels, these were medicine containers.

\section{TA 90/48P (Figs 4:10, 9i)}

Archaeological context: square KK, south-east corner of the corridor delimited by red brick wall; a public bath of the mid-Ptolemaic period (time of Ptolemy VI and later).

H. $5 \mathrm{~cm}$, W. $2.5 \mathrm{~cm}$.

Compact, pinkish-cream clay (5YR 7/4); surface with reddish-brown slip (5YR 5/3). The slip covers the entire external surface of the vessel except for two spots on the opposite side of the foot (possibly negatives of the fingers of the potter, left during the production process). The clay and the fabric indicate that the jar is an import in Tell Atrib.

\footnotetext{
${ }^{12}$ Rotroff 2006: 163, Fig. 70.542-544 (with further bibliography).
} 

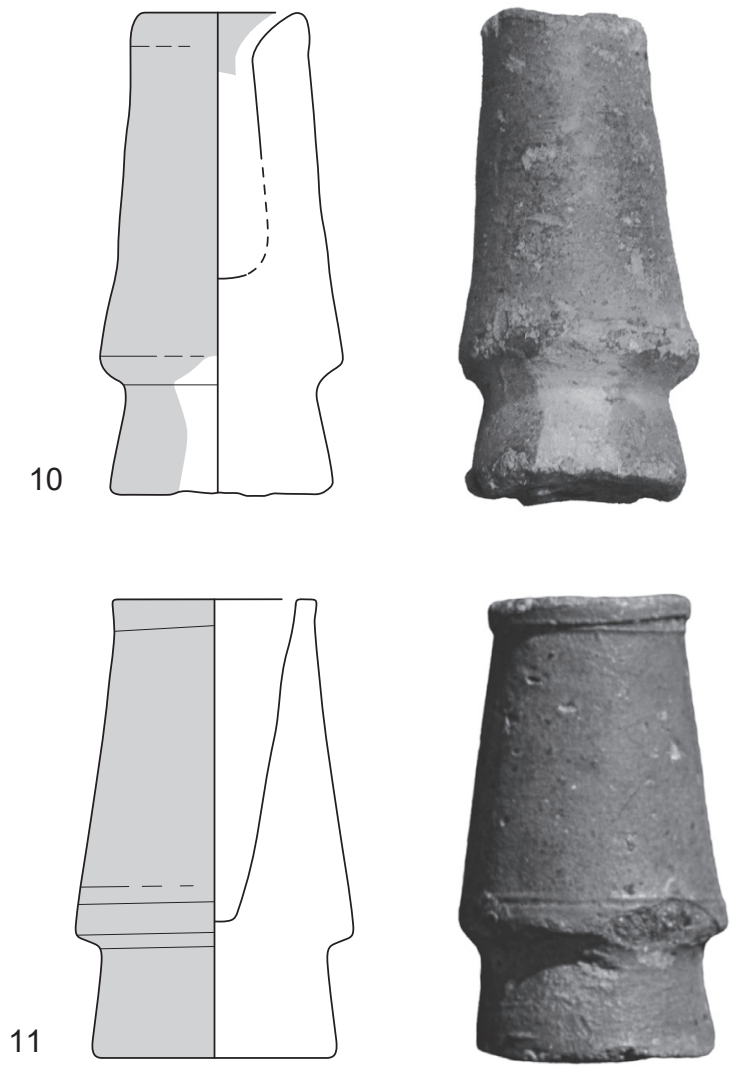

\section{0}

$5 \mathrm{~cm}$

4. Pottery miniature vessels (cat. nos 10-11) from Tell Atrib (Drawing: P. Mieliwodzki, M. Momot; digitizing: M. Momot; Phot. A. Południkiewicz).

\section{TA $94 / 133$ (Figs 4:11, 9j)}

Archaeological context: square CCC, room 237, 1.4m from the west wall of the room, $0.3 \mathrm{~m}$ from its south wall, $1 \mathrm{~m}$ below of the top of late-Ptolemaic walls; public bath of mid-Ptolemaic period (time of Ptolemy VI and later).

\section{H. $4.5 \mathrm{~cm}$, W. $3 \mathrm{~cm}$.}

Nile silt, brown (2.5YR 5/7), with a lot of inclusions: chaff, sand, lime particles and mica. Red slip. The clay and the fabric are typically local. This is a local imitation of a foreign form, possibly of Aegean origin. 

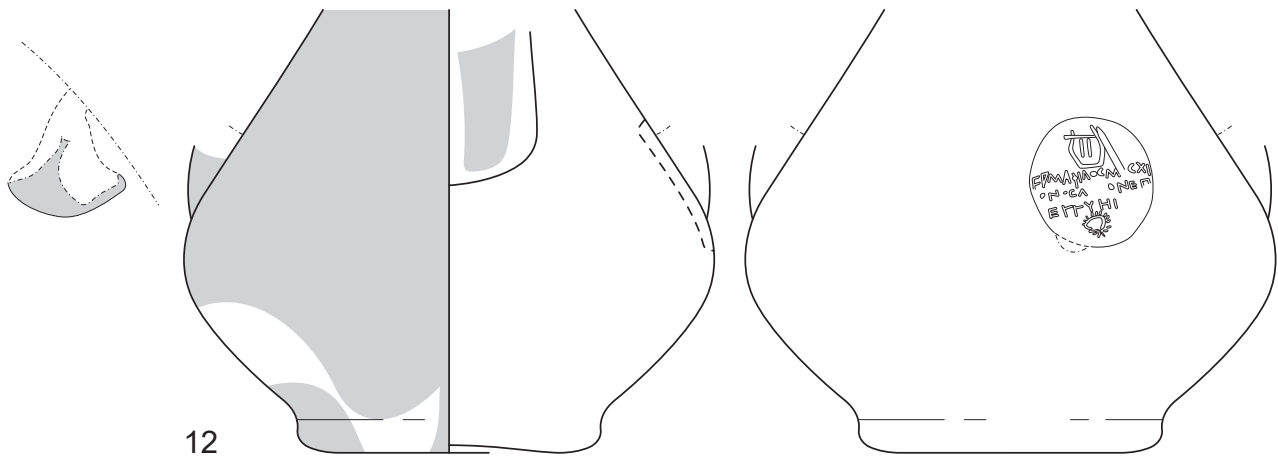

0

$5 \mathrm{~cm}$
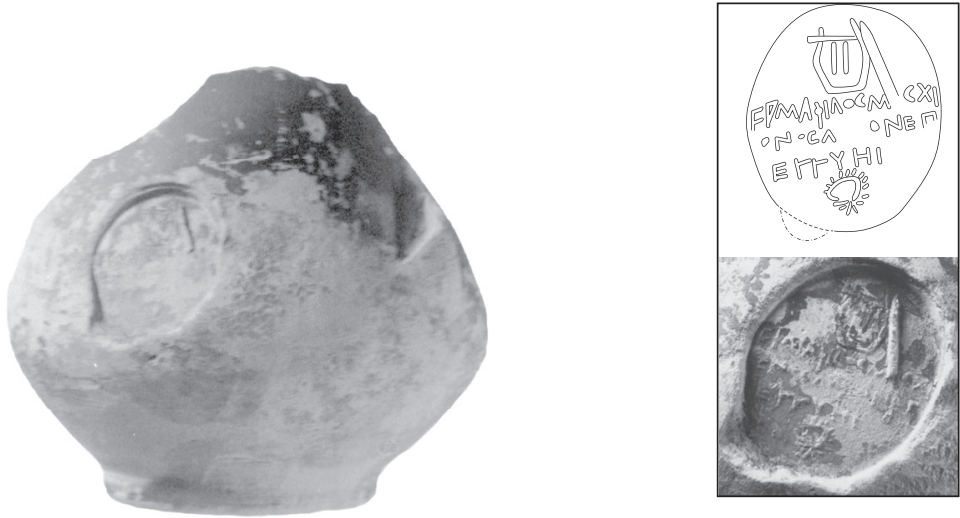

5. Pottery miniature vessel (cat. no. 12) from Tell Atrib (Drawing: M. Momot; digitizing: M. Momot; Phot. W. Jerke).

\section{SMall Globular VASE, CAT NO. 12 (Fig. 5)}

One vessel from Tell Atrib represents the form of a small vase with globular body and low foot, with very thick walls and extremely thick base. Traces of a handle are visible on the lower part of its shoulder. It is parallel to group A in the typology of Taborelli-Marengo, which equals type I of Sjöqvist and type II in the typology of Gül Işin. Vessels of this group/type are believed to be products of Sicilian workshops. Examples are well represented among finds from Sicily (especially Morgantina, but also Agrigentum and Syracusae), ${ }^{13}$ and the Apennine Peninsula including Elaia (Velia), ${ }^{14}$ and Pompei. ${ }^{15}$ They are also known

\footnotetext{
${ }^{13}$ For a general presentation of Sicilian finds, see: Sjöqvist 1960; Taborelli 2014; 2015.

${ }^{14}$ Vecchio 2006; cf. Taborelli, Marengo 2010: 216, no. 10, Fig. 7. The vessel carries a stamp impression with the inscription Nıкí $\lambda$ íkıov (reprinted as SEG LVI 1163).

${ }^{15}$ Vallarino 2003; cf. Taborelli, Marengo 2010: 217-218, no. 1, Fig. 8. The vessel carries a stamp impression with the inscription $\lambda$ ókıv accompanied by a monogram (reprinted as SEG LIII-2 1086).
} 
from the East, including Ephesus, ${ }^{16}$ Thessaloniki, ${ }^{17}$ Thracian Bisone, ${ }^{18}$ and Chersonesos on Crimea. ${ }^{19}$

\section{TA 93/1P}

Archaeological context: the northern part of square DDD, a layer of ash containing disturbed material from the mid- to late-Ptolemaic period. ${ }^{20}$

\section{H. $4.5 \mathrm{~cm}$, W. $5 \mathrm{~cm}$.}

Compact, fine, pink-yellowish clay (5YR 7/4). Grayish brown slip in the upper part of the vessel (10YR 3/2), and yellowish red (5YR 5/6-5/8) in the lower one. The slip flakes easily, especially in the lower part.

An oval stamp (H. $1.7 \mathrm{~cm}$, W. $1.2 \mathrm{~cm}$ ) is impressed on the upper part of the belly. It has a Greek inscription in the middle, a lyre above it and a wreath below it. An oblique roller is visible in the upper right-hand quarter of the stamp, partly covering the lyre and the letter omicron towards the end of line 1 of the inscription, probably stuck onto the surface incidentally during the stamping process or immediately after it. The letters of the inscription are of extremely small dimensions (less than $2 \mathrm{~mm}$ ). The script is rather clumsy.

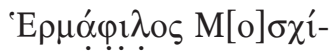

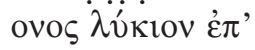

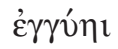

Hermaphilos son of Moschion (produced this) guaranteed lykion.

A vessel found on the Athenian agora bears the impression of an oval stamp with the

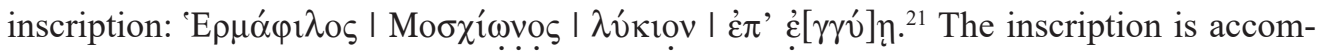
panied by a wreath (on the left) and another device, possibly a club, on the right. The

\footnotetext{
${ }^{16}$ Mitsopoulos-Leon 1991: 148-149, Pl. 214; cf. Taborelli, Marengo 2010: 215, no. 8, Fig. 5. The vessel

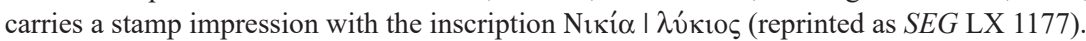

${ }^{17}$ Georgaki, Zographou 2001: 65-86; cf. Taborelli, Marengo 2010:216, no. 9, Fig. 6. The vessel carries a stamp impression with the inscription Nıкí |

${ }^{18}$ Zmeikova 1985; cf. Taborelli, Marengo 1998: 260, and Fig. 2.7a-b. The vessel carries a stamp impression

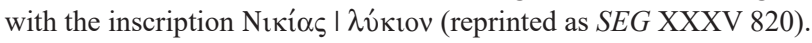

${ }^{19}$ Pruglo 1966: 193 and 200-201, Figs 2.2 and 3.7; cf. Taborelli, Marengo 1998: 258, and Figs 1.6 and 6.3.

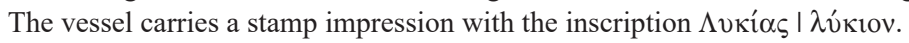

${ }^{20}$ For a context of the find, see: Myśliwiec, Abu Senna 1995: especially 210-211, with Fig. 5, where this vessel is mentioned and illustrated. See also: Myśliwiec 2000b: 258, Pl. 130e.

${ }^{21}$ Rotroff 1997: 424, n. 1776, Fig. 105, Pl. 139; Stampolidis, Tassoulas (Eds) 2014: 283, no. 148 (M. Liaska). The vessel was mentioned briefly in Sjöqvist 1960: 82; see also: Taborelli, Marengo 1998: 254.
} 
stamps impressed on the vessels from Athens and Tell Atrib are not the same but obviously belonged to the same man. This is indicated primarily by the onomastics, but also by the use of wreath as one of the two devices. Interestingly the other device is different here and there (lyre versus club[?]). Obviously, Hermaphilos son of Moschion used two (or more) stamps during his professional career as a druggist. More importantly, he stamped vessels of different types as containers for medicine, even if the medicine put into them was the same: the vessel from Athens represents type V in the typology of Gül Işin (Taborelli and Marengo group D), whereas the vessel from Tell Atrib is Işin type II (Taborelli and Marengo group A).

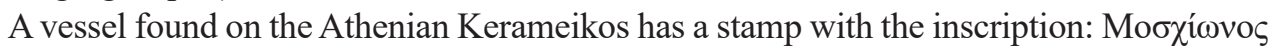
$\lambda$ v́к10v. ${ }^{22}$ Considering that the medical profession was frequently passed from one generation to the next in antiquity one can wonder if the druggist mentioned in the inscription of the Kerameikos vessel was not identical with the father of Hermaphilos. ${ }^{23}$ We know a physician with the name Moschion (first century BC), the author of works devoted to cosmetics, dietetics and pulse, ${ }^{24}$ and an oculist named Hermophilos (time unspecified) whose receipt for an eye salve is quoted by Galen. ${ }^{25}$ An identification of our Hermaphilos and Moschion with these men is possible.

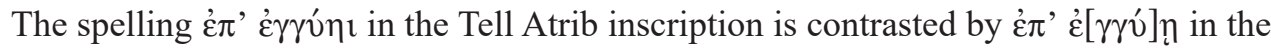
Athenian one. ${ }^{26}$ The difference in spelling mirrors phonetic phenomena affecting the Greek language of Hellenistic times. In the early Hellenistic period (third century BC) the $/ \mathrm{i} /$ of long diphthongs (/āi/, /ēi/, /ōi/) was still commonly pronounced, at least at the end of the dative singular, and was recorded in script as an iota adscript, as attested by contemporary inscriptions and papyri. ${ }^{27}$ The situation changed gradually in the mid/late Hellenistic period: at that time, /i/ became mute in the context here discussed and, as a consequence, started to be omitted in the writing until it was almost totally abandoned by the time of the early Imperial period. The two stamps of Hermaphilos son of Moschion dating probably from the second/first century $\mathrm{BC}^{28}$ testify to the intermediary period when the two spellings were used side by side.

In addition to both stamps of Hermaphilos son of Moschion the expression غ̇ ' ' is found in an inscription on another lykion vessel found in Tell Atrib (below, cat. no. 15), on two vessels, one from Athens and one from Sukas in north Syria, stamped with the

${ }^{22}$ Rousopoulos 1870: 2130; Taborelli, Marengo 1998: 259. The inscription is reprinted as SEG XLI 241.

${ }^{23}$ Such a possibility was apparently taken into consideration by Taborelli, Marengo 1998: 235 and 259.

${ }^{24}$ Deichgräber 1933; Nutton 2000.

${ }^{25}$ Gossen 1913.

${ }^{26}$ Susan Rotroff gives $\dot{\varepsilon} \pi ’ \dot{\varepsilon}[\gamma \gamma u ́] \eta(1)$, as if iota were erroneously omitted or the word was recorded in an abbreviated form.

${ }^{27}$ For Greek papyri from Egypt, see: Clarysse 1976; for inscriptions, see e.g.: Threatte 1980: 353-367, especially 360 . The last author notes that the earliest case of $\eta$ for $\eta 1$ in the dative observable in the Attic inscriptions is in a decree of 204/203 BC. The two spellings became fully interchangeable in the second half of the second century $\mathrm{BC}$ in inscriptions from Attica.

${ }^{28}$ Such a date can be suggested for the Tell Atrib find on the basis of the context. The Athenian find occurred in early Imperial context as noted by Susan Rotroff. 
same inscription, ${ }^{29}$ as well as on an object from Myrmekion in the Crimea. ${ }^{30}$ It is interesting to observe that the jars in question represent two different types and were most probably produced in two different areas, located at quite a long distance from one another,

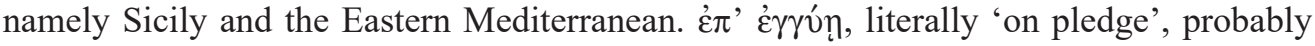
means 'guaranteed' (thus in translation above) or 'of the first quality'. The inscription says that the vessel contains a medicine, the quality of which is guaranteed by the name of its producer. ${ }^{31}$

\section{SMALl BICONIC VESSELS, CAT. NOS 13-14 (Fig. 6)}

Two examples from Tell Atrib represent the form of a small vessel with a biconic body. The first one (cat. no. 13) is characterised by thick walls, a high solid foot, flat underneath, and a slightly out-turned rim. It corresponds to the Işin type III, Hershkovitz type B. It is definitely an import, possibly from Asia Minor (Lycia?).

The second one (cat. no. 14) is of angular profile, wide mouth with an out-turned rim, and a solid foot (rather irregular in this case). The vessel represents Işin type III, Hershkovitz type B (lacking in Taborelli and Marengo classification). The richest collection of vessels of this type (over 100 items) was found during archaeological work carried out by a Turkish team in Patara, Lycia, in 1980s and 1990s. Gül Işin considered these vessels as local Lycian products. ${ }^{32}$ Similar biconical vessels are known from other locations in the Eastern Mediterranean, from mainland Greece through the Aegean, south coast of Asia Minor, Cyprus to Palestine and Egypt. ${ }^{33}$ Whether they were produced locally or were imported from Lycia (or from elsewhere) is difficult to say without a close technological examination. The Tell Atrib vessel is surely an import, most probably from Lycia itself. The Patara finds are dated to late-Hellenistic times (end of second/first century BC) by Gül Işin. This may also be the date for the Tell Atrib specimen.

${ }^{29}$ Athenian vessel: Rotroff 1997: 424, no. 1775, Fig. 105, P1. 139; Sukas vessel: Lund 1986: 159-160, Fig. 148, P1. 49.60 (non vidimus); cf. Taborelli, Marengo 2010: 215, no. 7, Fig. 4. The inscription reads: Nikí $\varsigma_{\varsigma}$

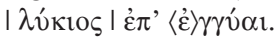

${ }^{30}$ Pruglo 1966; cf. Taborelli, Marengo 1998: 262, and Fig. 5.21. The inscription is in retrograde. It reads:

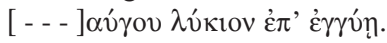

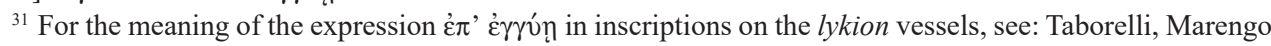
1998: 246.

${ }^{32}$ Işin 2002: 93-95.

${ }^{33}$ Işin 2002: 90, with nn. 61-73, mentions (with bibliographic references) following sites: Athens, Piraeus, Corinth, Delos, Samos, Ephesus, Patara, Perge, Tarsus, Paphos, Dor, Samaria, Jerusalem, Masada. To them, one can add: Pylos (cf. Vivliodetis, Giannopoulou 2014: 55 with Fig. 5), Kenchreai (Adamshek 1979: 118-119, RC 25, P1. 33 [four examples]), Abdera (Stampolidis, Tassoulas (Eds) 2014: 284-285, no. 150 [C. S. Kallintzi]; cf. Vivliodetis, Giannopoulou 2014: 54, n. 56 who note that this vessel is one of the four discovered in Abdera), Naxos (Ko $\lambda_{1} \alpha$ 2006: 86, 203-204, Fig. 194, Pl. 8), Priene (Zahn 1904: 425, no. 87, Fig. 538), and Alexandria (Pagenstecher 1913: Pl. XLV,6 and 9). Two further pots from Delos are published in: Stampolidis, Tassoulas (Eds) 2014: 285, nos 151-152 (P.J. Chatzidakis). Interestingly, vessels of this type are sometimes designated as amphora stoppers in the scholarly literature (thus for example Adamshek 1979: 118-119, RC 25). 

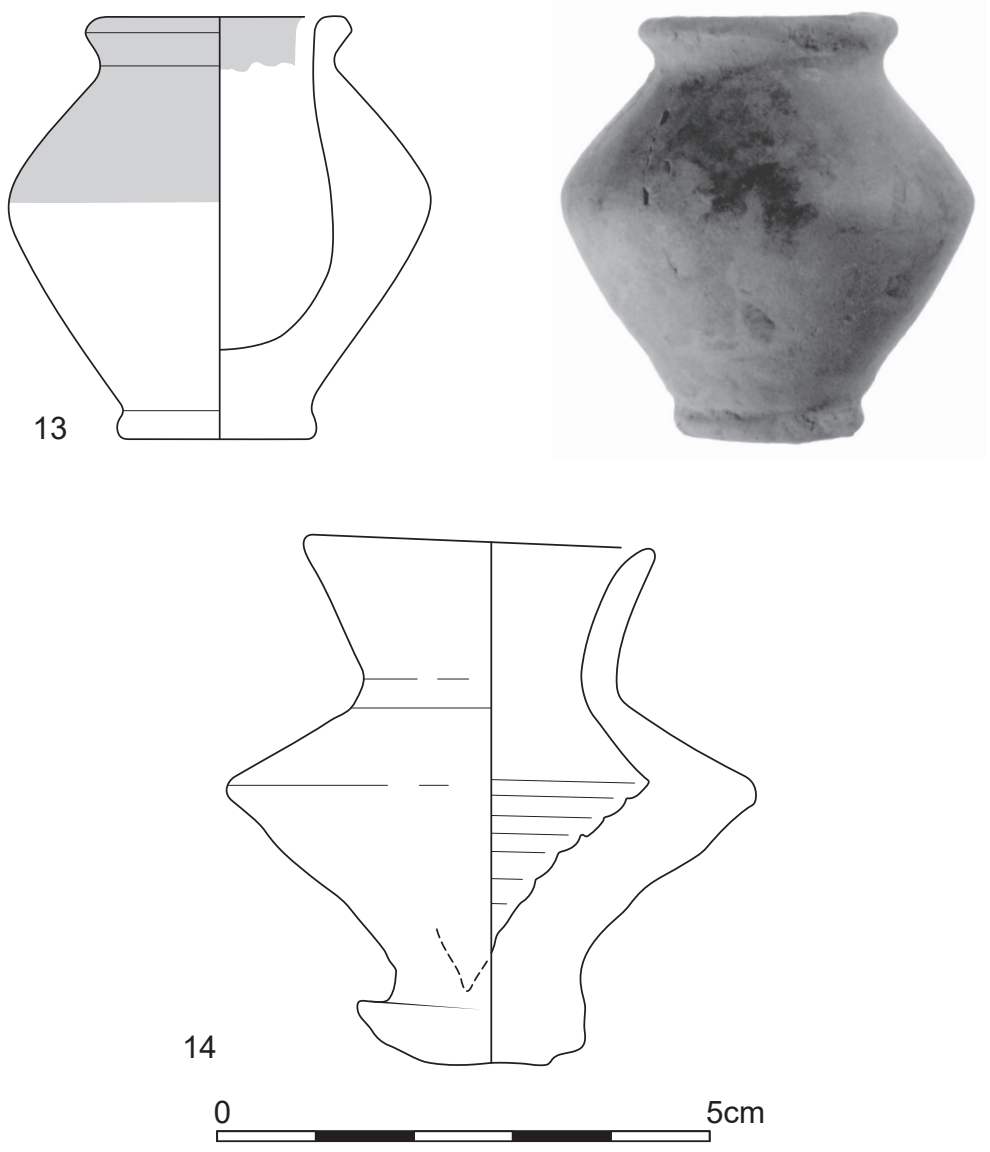

6. Pottery miniature vessels (cat. nos 13-14) from Tell Atrib (Drawing: P. Mieliwodzki, M. Momot; digitizing: M. Momot; Phot. W. Jerke).

\section{TA 92/12 (Fig. 6:13)}

Archaeological context: room 165, $0.4 \mathrm{~m}$ from the north wall, $2.3 \mathrm{~m}$ from the west wall, $2 \mathrm{~m}$ below the top of the west wall; public bath of mid-Ptolemaic period (time of Ptolemy VI and later).

H. $4.2 \mathrm{~cm}$, W. $4.2 \mathrm{~cm}$; capacity $10 \mathrm{~cm}^{3}$.

Fine, cream (2.5YR 6/4), well levigated clay, visible tiny pieces of mica. Upper part of the body covered with red slip (7.5R 4/6). 


\section{TA 91/WITHOUT INVENTORY NUMBER (Fig. 6:14)}

Archaeological context: square CC, room 137, 0.6-0.7m below the top of the walls of the room, in a disturbed context (material from the Hellenistic to late-Roman periods), in the earth layer under a rubbish heap.

\section{H. $5.3 \mathrm{~cm}$, W. $5.3 \mathrm{~cm}$.}

Fine cream clay (7.5YR 6/6), some mica and lime particles.

\section{Small JUGLet, CAT. NO. 15 (Figs 7, 9k)}

Small juglets with a flat base, cylindrical body, short shoulders, cylindrical neck passing into a round, slightly out-turned rim are represented by one vessel from Tell Atrib. A single, broad strip-handle runs from the shoulders to the rim.

The shape of the juglet is paralleled by ten or so vessels coming from different sites mostly situated in the Eastern Mediterranean. Four examples were discovered during American excavations on the Athenian agora and were published by Susan Rotroff who dated them to the two first centuries after Christ. ${ }^{34}$ Three further vessels are known from Egypt: two came to light in Alexandria, ${ }^{35}$ one is of unknown Lower Egyptian provenance. ${ }^{36}$ Three examples were found in the Syro-Palaestinian area: one in Sukas in north Syria, ${ }^{37}$ and two in Dor near Haifa. ${ }^{38}$ An example of unknown provenance but undoubtedly from present-day Lebanon is kept in a private collection in Beirut. ${ }^{39}$ Moreover, Yves Calvet mentions numerous vessels of this shape discovered in Cypriote Salamis. ${ }^{40}$ A fragmentary vessel came to light in Hellenistic layers of Myrmekion in the Crimea. ${ }^{41}$ Three vessels of similar shape are known from the Apennine Peninsula: two were found in Tarentum, ${ }^{42}$ and one in Viterbo. ${ }^{43}$ These three objects are known only through old, nineteenth-century, imperfect publications, which makes their typological and technological assessment difficult.

\footnotetext{
${ }^{34}$ Rotroff 1997: 424, nos 1774-1777, Fig. 105, Pl. 139. Her no. 1775 is described and illustrated in Stampolidis, Tassoulas (Eds) 2014: 282, no. 147 (M. Liaska).

${ }^{35}$ Rowe 1942: 59, no. 16, P1. XVIII, and 62.

${ }^{36}$ Perdrizet 1921: 128, no. 352, P1. CXXVI; cf. Taborelli, Marengo 1998: 230, Fig. 5.20, and 254.

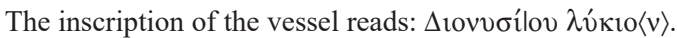

${ }^{37}$ Lund 1986: 159-160, Fig. 148, P1. 49.60; cf. Taborelli, Marengo 2010: 215, Fig. 4.

${ }^{38}$ G'uz-Zilberstein 1995: 302-303, nos 45483 and 45487, Fig. 6.25:1-2 (non vidimus); cf. Taborelli, Marengo 2010: 214, no. 6, Fig. 3, and 213-214, no. 1, Fig. 2. The first of these vessels has the inscription

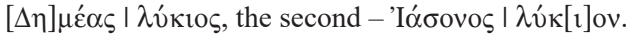

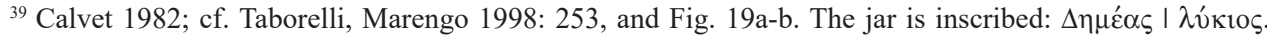
The inscription is reprinted as SEG XXXII 1618.

${ }^{40}$ Calvet 1982. According to the last author the vessels were without stamps. As far as we are aware the objects have remained unpublished.

${ }^{41}$ Pruglo 1966.

${ }^{42}$ Taborelli, Marengo 1998: 256-257, Fig. 3.9a-b, 3.10a-c on p. 223. Both vessels carry the inscription 'Ió бovos I $\lambda$ úкıv.

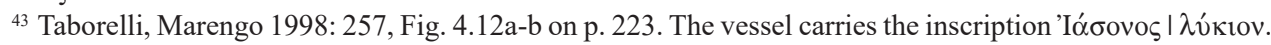




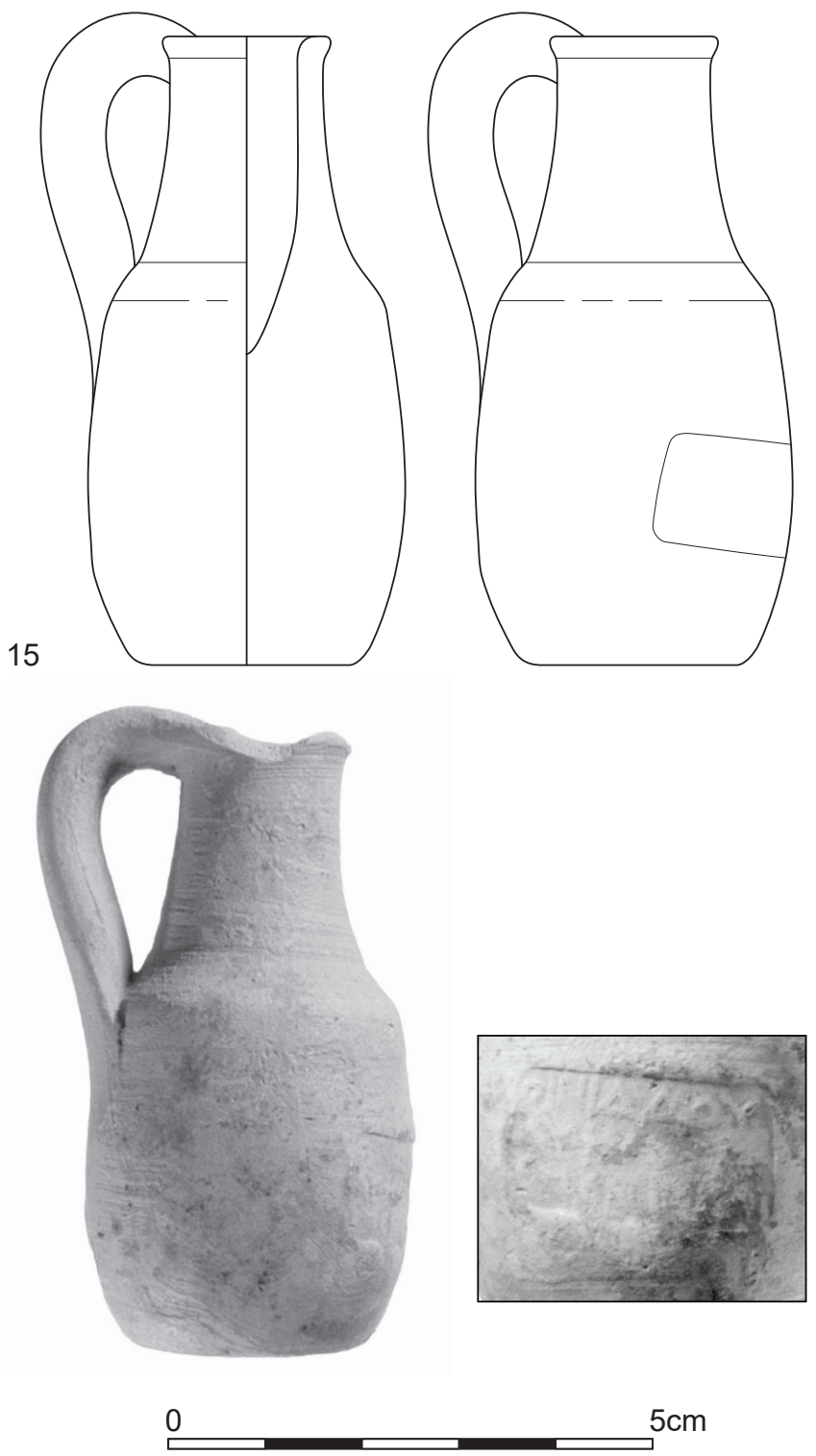

7. Pottery miniature vessel (cat. no. 15) from Tell Atrib (Drawing: P. Mieliwodzki; digitizing: M. Momot; Phot. W. Jerke).

Based on their reported find-spots, Taborelli and Marengo made out of them a separate 'Greater Greece-Group', whereas Gül Işin, not without reason, considered them as belonging to the same type as the listed above objects from the Eastern Mediterranean. The name 'Athenian Agora/Louvre', which Işin coined for this type, is misleading, however, for two reasons: the jar from Tarentum that she labels 'Louvre' was in fact kept in a private collection in Paris in the nineteenth century and the vessels discovered on the 
agora of Athens are definitely not Athenian products, as noted by Susan Rotroff. Taborelli and Marengo ascribe the entire group to the Eastern Mediterranean without specifying the exact area.

15. TA $91 A / 140$

Archaeological context: square WW, $2.3 \mathrm{~m}$ from western edge of the square, $1.8 \mathrm{~m}$ below the ground level; public bath of mid-Ptolemaic period (time of Ptolemy VI and later), under a burnt layer, in a ceramic deposit.

H. $6.5 \mathrm{~cm}$, W. $3 \mathrm{~cm}$.

Grey-yellowish clay; buff-orange slip, without gloss.

In the lower part of the body, opposite the handle, a rectangular stamp $(1.1 \times 2.2 \mathrm{~cm})$ was impressed. ${ }^{44}$

Oiviósov

$\lambda$ úкiov

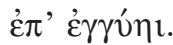

Guaranteed lykion (produced) by Oiniades.

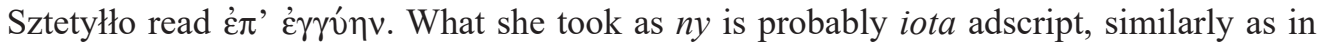
cat. no. 12 (see commentary there) and in the parallel objects from Athens and Sukas in Syria (see above). The personal name Oiniades is especially well attested in Athens ${ }^{45}$ but was also known elsewhere.

FAIENCE MINIATUR BEAKER, CAT. NO. 16 (Figs 8:16, 91)

The only faience medicinal vessel from Tell Atrib is beaker with flat base, walls narrowing towards the out-turned flattened rim.

16. TA $91 \mathrm{~A} / 144$

Archaeological context: between sectors JJ and UU, 3m from the northern border of the sectors, $1 \mathrm{~m}$ below the crest of a wall running across sector UU from north to south. Bottom of a layer of burning dated to the turn of the third century BC (coin of Ptolemy II TA 91A/124).

H. $3 \mathrm{~cm}$, W. $3.2 \mathrm{~cm}$.

\footnotetext{
${ }^{44}$ Published in: Sztetyłło 2000: 133-134, no. 182, with a photo.

${ }^{45}$ Six persons of this name listed in: Osborne, Byrne (Eds) 1994.
} 

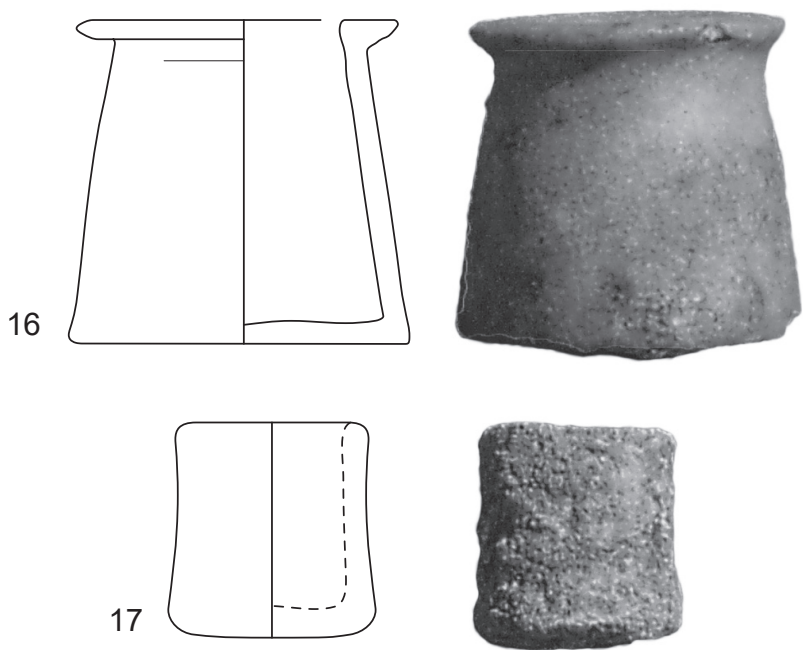

0

$5 \mathrm{~cm}$

8. Faience (cat. no. 16) and bronze (cat. no. 17) miniature vessels from Tell Atrib (Drawing: P. Mieliwodzki, M. Momot; digitizing: M. Momot; Phot. K. Myśliwiec).

Faience, white paste, light green glaze. ${ }^{46}$

Miniature BRONZE CUP, CAT. NO. 17 (Figs 8:17, 9m)

The only bronze medicinal vessel from Tell Atrib is a cup with vertical walls. ${ }^{47}$

\section{TA 91P/WITHOUT INVENTORY NUMBER}

Archaeological context: unknown. Since the object was discovered during the 1991 season, it must have originated in the Ptolemaic strata in the north-western part of the excavated area, either within the bath complex or in the industrial quarter.

H. $2.1 \mathrm{~cm}, W .2 .1 \mathrm{~cm}$ (near the foot).

Bronze.

\section{CONCLUSIONS}

Among seventeen vessels published in this article, fifteen are made of clay, one of faience, and one of metal. The ceramic vessels are either imports (cat. nos $1-4,9-10,12-15$ ) or

\footnotetext{
${ }^{46}$ Published in: Welc 2014: 172-174, cat. no. 158.

${ }^{47}$ Note that the drawing of the object was prepared from the photo.
} 
a
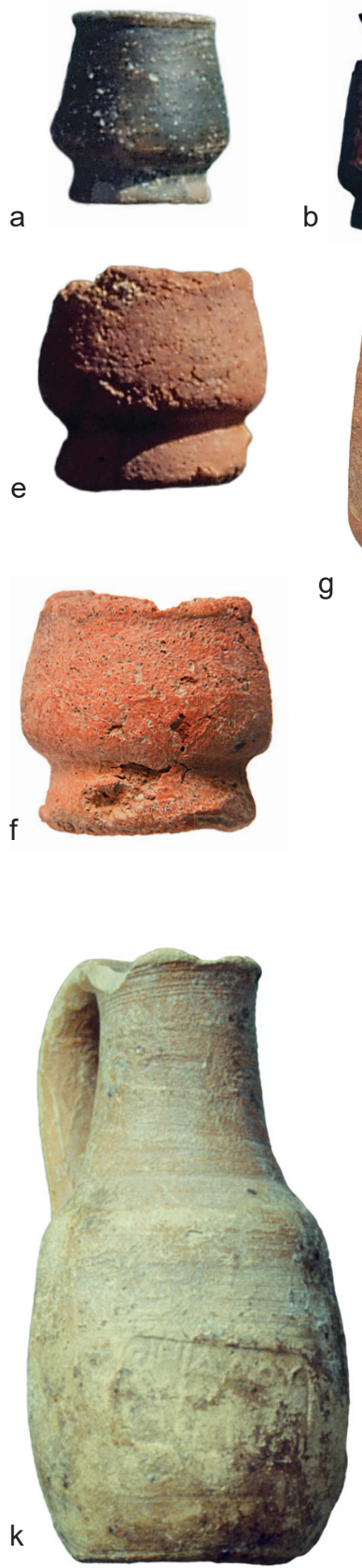

b

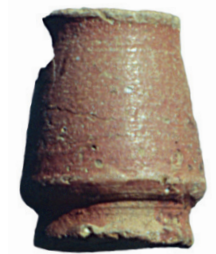

C

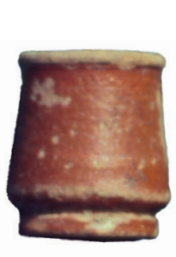

d
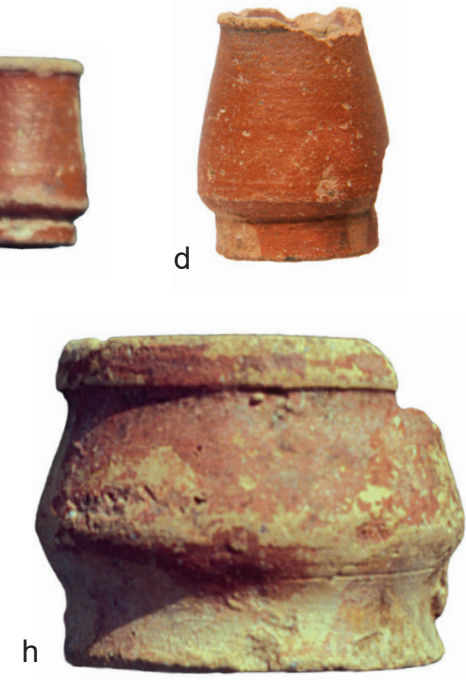

j
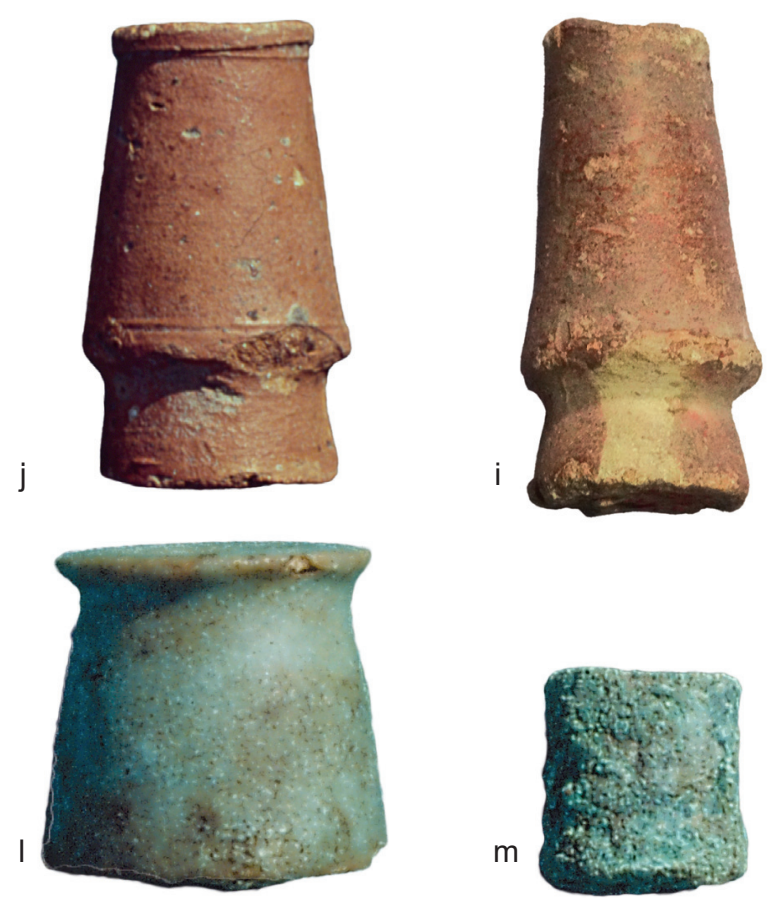

0

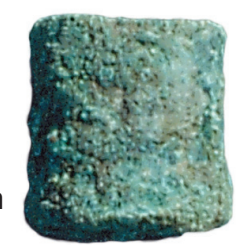

$5 \mathrm{~cm}$

9. Selection of miniature vessels from Tell Atrib: a-d. cat. nos 1-4; e-j. cat. nos 6-11; k-m. cat. nos 15-17

(Phot. W. Jerke, K. Myśliwiec, A. Południkiewicz). 
local imitations of imported models (cat. nos 5-8, 11). Among the imported objects one originated from Sicily (cat. no. 12), one, or possibly two, from Lycia (cat. nos 13-14) and the remaining ones from an undeterminable part of the Eastern Mediterranean. The faience vessel could have been produced in Egypt, ${ }^{48}$ but the origin of the metal cup cannot be determined.

Two vessels (cat. nos 12 and 15) were destined for containing a medicine called lykion as specified by their inscriptions. Also cat. no. 14, which is most probably an import from Lycia, the homeland of the lykion plant, seems to be a lykion pot. The same holds true, even if with less probability, for cat. no. 13. Moreover, the remaining vessels, perhaps with the exception of cat. no. 8, could have been bottles for medicines too, for lykion or some other substance.

Lykion was a medicine produced from a plant of the same name so-called because of its being endemic to the region of Lycia and Cappadocia in Asia Minor, although it also grew elsewhere in the Mediterranean. ${ }^{49}$ The plant is commonly identified as buckthorn (either Rhamnus cathartica or Rhamnus infectoria L.). The name lykion was also applied to a plant growing in India (identified as Berberis lycium royale or Acacia catechu Willd) and a medicine produced from it. The Indian lykion was considered especially beneficial and effective by ancient medicine writers. It was traded along the southern sea routes to the Mediterranean and sold there at extremely high prices. Moreover, a passage of Pliny (Nat. hist., XXVI, 87, 140) suggests that medicines obtained from other plants, e.g. gentian, could have been called lykion, too. The lykion medicine was extracted from the branches and woody roots of the lykion plant. Rich in astringent tannins, it was used to treat a variety of illnesses and disorders including psoriasis, rabies, dysentery, otitis, tonsil inflammations, haemorrhoids and torn gums, however, it was especially recommended in the case of ophthalmological problems. Lykion could have been used pure or as an element of various compositions assuming the form of an ointment or a salve. The relatively high number and the wide distribution of the lykion pots, together with frequent mentions of the lykion in Greek and Latin medical writings, testify to the great popularity of the lykion medicine in antiquity. In contrast with that, lykion is rarely mentioned in Greek papyri of Egypt. We were able to find only four attestations: P.Haun. III 47, 11. 2 and 6 (two receipts for eye salves called 'Theodotion' and 'Another Theodotion' respectively), ${ }^{50}$ MPER XIII 2, 1.9 (a receipt for an eye medicine), ${ }^{51}$ P.Vindob G 35250, 1. $\rightarrow 3$ (a receipt for an eye medicine called 'Malabathrinon'), ${ }^{52}$ and P.Vindob G 42050, 1. $\downarrow 27$ (a receipt for a medicine against disorders of the wind-pipe). ${ }^{53}$

The medicinal vessels known so far were discovered in a variety of contexts. In Morgantina, vessels of types 1 and 2 (according to Sjöqvist typology) occurred either in "profane

48 Thus Welc 2014: especially 47-53.

${ }^{49}$ Generally on lykion, see: Simpson 1853; 1855; Sjöqvist 1960: 82; Boon 1983; Casson 1989: 192-193; Krug 1993: 109-110; Taborelli, Marengo 1998: 213-215.

${ }^{50}$ Cf. Youtie 1985.

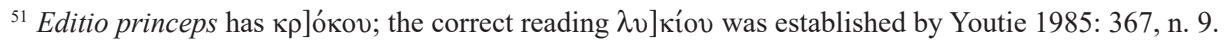

${ }^{52}$ Published by F. Mitthof in: Andorlini (Ed.) 2009: 123-141.

${ }^{53}$ Published by F. Mitthof in: Andorlini (Ed.) 2009: 143-154. 
areas such as houses and shops' whereas those of type 3 were found in 'holy places, in this case in the various shrines of Demeter and Kore or their immediate vicinity'. This prompted Sjöqvist to think that the former 'were purely practical in scope and used to meet the exigencies of daily life', while the latter 'also served another purpose', namely that they 'were preferred as votive gifts to the gods'. ${ }^{54}$ In Athens, the vessels came to light mainly on the agora, i.e. in the commercial context; however, one example was found in the Kerameikos, i.e. in a sepulchral context. On the island of Delos, the find-spots of the vessels included private houses, the Agora of the Italians, and the Terrace of the Lions. In Patara, one example was found in the so-called Harbour Bath, three other were stray finds, and the remaining objects were obtained from the necropolis, however, not from burial contexts but from strata covering the graves. ${ }^{55}$

The Tell Atrib vessels published in this paper occurred mainly within a bath complex of the mid-Ptolemaic period, some of them were found in the neighbouring industrial quarter. The industrial quarter was probably founded in early-Ptolemaic times and initially occupied the entire south-western part of the excavated area, to the south-west of Kom Sidi Yousouf. It included ceramic workshops (both for producing vessels and figural terracottas), lime-kilns, bakeries, and probably also a goldsmith's workshop. ${ }^{56}$ In the mid-Ptolemaic period, possibly, under Ptolemy VI, the northern part of the quarter was erased to provide space for a bath complex. The latter consisted of a series of small basins - each, as a rule, was destined for one person only - neighbouring a lavishly decorated room, no. 159, probably used as a place for some gatherings. Karol Myśliwiec is of the opinion that this bath complex had ritual functions, being connected with a temple of an Egyptian god, the site of which is now covered by the tomb of Sidi Yousouf. ${ }^{57}$ Based on the discovery of a small schist stela showing Horus standing on crocodiles, Ewa Laskowska-Kusztal posited the hypothesis that healing activity also took place there. ${ }^{58}$ It included, according to Laskowska-Kusztal, both magical practices, basing on analogy with events from Egyptian myths such as the story of child Horus, and physical ones, using the medical properties of water and bathing. Medicinal containers obtained from the bath complex and the neighbouring industrial quarter could have been connected with this healing activity.

\section{Acknowledgments}

The authors wish to thank Karol Myśliwiec, the Director of the Polish-Egyptian archaeological Mission excavating Tell Atrib, for encouragement and help, and Vivienne Callender for improving the English.

${ }^{54}$ Sjöqvist 1960: 78.

${ }^{55}$ Işin 2002: 85. The author notes that only one vessel occurred in the tomb itself.

${ }^{56}$ Generally, for the Ptolemaic workshops in Tell Atrib, see: Myśliwiec 1996a; 1996b; 2000a: 30-33. The ceramic production is attested by the pottery kiln and numerous unfired vessels, especially bowls with incurved rim, for which see: Południkiewicz 1995.

${ }^{57}$ According to Myśliwiec (1997), this late Dynastic/early Ptolemaic temple was dedicated to Renenutet, whose name occurs on a seal found within a bath complex; cf. also: Myśliwiec 1998: 128.

${ }^{58}$ Laskowska-Kusztal 1995. 


\section{References}

Abbreviations for editions of papyri follow: Sosin, J.D., Bagnall, R.S., Cowey, J., Depauw, M., Wilfong, T.G., Worp, K.A. (Eds) 2011: Checklist of Editions of Greek, Latin, Demotic, and Coptic Papyri, Ostraca and Tablets, last updated 1 June 2011, http://library.duke.edu/rubenstein/scriptorium/papyrus/texts/clist.html (accessed April 12, 2016)

Adamsheck, B. 1979: Kenchreai. Eastern Port of Corinth IV: The Pottery, Leiden

Andorlini, I. (Ed.) 2009: Greek Medical Papyri II, Florence

Boon, G.C. 1983: Potters, Oculists and Eye-Troubles, Britannia XIV, 1-12

Calvet, Y. 1982: Pharmacopée antique: Un pot à lykion de Beyrouth, [in:] Archéologie au Levant: Recueil à la mémoire de Roger Saidah, Collection de la Maison de l'Orient méditerranéen 12, Série archéologique 9, Lyon, 281-286

Casson, L. 1989: The Periplus Maris Erythraei: Text with Introduction, Translation and Commentary, Princeton-Guildford

Clarysse, W. 1976: Notes on the use of the iota adscript in the third century BC, ChronEg 51, $150-166$

Deichgräber, K. 1933: Moschion (9), [in:] RealEnc XVI, 349-350

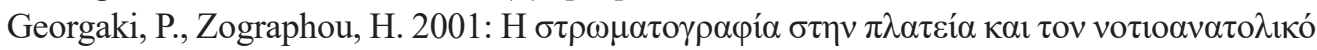

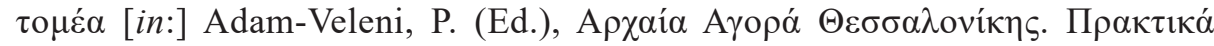

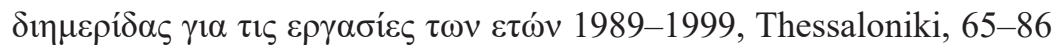

Gossen, H. 1913: Hermophilos (2), [in:] RealEnc VIII, 902

G'uz-Zilberstein, B. 1995: Selected Loci of the Hellenistic and Roman Periods. The Typology of the Hellenistic Coarse Ware, [in:] Stern, E. (Ed.), Excavations at Dor, Final Report I B: Areas A and C: The Finds, Jerusalem, 289-312

Hershkovitz, M. 1986: Miniature Ointment Vases from the Second Temple Period, IEJ 36, $45-51$

Işin, G. 2002: Ointment or Medicine Vessels from Patara: An Overview of a Simple Hellenistic Form in the Ancient Mediterranean World, AA 2002/2, 85-96

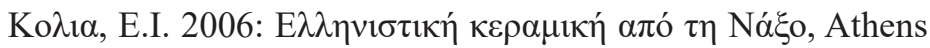

Krug, A. 1993: Heilkunst und Heilkult. Medizin in der Antike, Munich

Laskowska-Kusztal, E. 1995: La stèle d'Horus sur les crocodiles d'Athribis, EtudTrav XVII, 85-93

Lund, J. 1986: Sūkās VIII: The Habitation Quarters, Historisk-filosofiske Skrifter 12, Copenhagen

Mitsopoulos-Leon, V. 1991: Die Basilika am Staatsmarkt in Ephesos. Kleinfunde 1: Keramik hellenistischer und römischer Zeit, Forschungen in Ephesos IX 2/2, Vienna

Myśliwiec, K. 1996a: Les ateliers d'Athribis ptolémaïque, Archeologia (V) XLVII, 7-20 Myśliwiec, K. 1996b: In the Ptolemaic workshops of Athribis, EgArch 9, 34-36

Myśliwiec, K. 1997: Ermouthis à Athribis, [in:] Dijk, J. van (Ed.), Essays on Ancient Egypt in Honour of Herman te Velde, Egyptological Memoirs 1, Groningen, 259-266 
Myśliwiec, K. 1998: La fonction des bains publics de l'époque ptolémaïque à Athribis, Kwartalnik Historii Kultury Materialnej 46/1-2, 123-138

Myśliwiec, K. 2000a: Rescue Excavations at Tell Atrib in 1985-1995, [in:] Myśliwiec, K., Sztetyło, Z., Tell Atrib 1985-1995 I, TCAM 34, Varsovie, 9-49

Myśliwiec, K. 2000b: Researches on Hellenistic Pottery from Athribis (Lower Egypt), [in:]

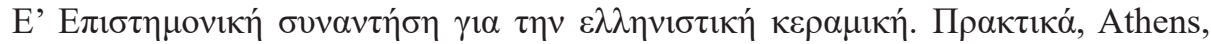
$253-258$

Myśliwiec, K. 2009: Contexte archéologique, [in:] Myśliwiec, K., Krzyżanowska, A., Tell Atrib 1985-1995 II, Warsaw, 15-69

Myśliwiec, K. 2011: L'acquis des fouilles de Tell Atrib pour la connaissance de l'époque ptolémaïque, [in:] Meyza, H., Zych, I. (Eds), Classica Orientalia. Essays Presented to Wiktor Andrzej Daszewski on his 75th Birthday, Warsaw, 387-398

Myśliwiec, K., Abu Senna, S. 1995: Polish-Egyptian Excavations at Tell Atrib in 19911993, EtudtTrav XVII, 205-240

Nutton, V. 2000: Moschion [4], [in:] Cancik, H., Schneider, H. (Eds), Der Neue Pauly: Enzyklopädie der Antike 8, Stuttgart, 413

Osborne, M.J., Byrne, S.G. (Eds) 1994: Lexicon of Greek Personal Names II: Attica, Oxford

Pagenstecher, R. 1913: Die Gefässe in Stein und Ton; Knochenschnitzereien, Expedition Ernst von Sieglin, Ausgrabungen in Alexandria II: Die griechisch-aegyptische Sammlung Ernst von Sieglin 3, Leipzig

Perdrizet, P. 1921: Les terres cuites grecques d'Egypte de la Collection Fouquet, Nancy-ParisStrasbourg

Południkiewicz, A. 1992: Local imitations of Greek pottery found in Tell Atrib, CCE 3, 95-101

Południkiewicz, A. 1995: Unfired pottery from Ceramic Workshops at Tell Atrib, [in:] Meyza, H., Młynarczyk, J. (Eds), Hellenistic and Roman Pottery in the Eastern Mediterranean - Advances in Scientific Studies. Acts of the II Nieborów Pottery Workshop, Nieborów, 18-20 December 1993, Warsaw, 299-329

Пругло, В.И. 1966: Эллинистические флаконы для лекарства, SovArch 196/1, 192-202

Rotroff, S.I. 1997: Hellenistic Pottery: Athenian and Imported Wheelmade Table Ware and Related Material, The Athenian Agora XXIX, Princeton

Rotroff, S.I. 2006: Hellenistic Pottery. The Plain Wares, The Athenian Agora XXXIII, Princeton

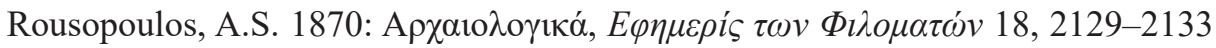

Rowe, A. 1942: Painted pottery situla from 'Pompey's Pillar', BSAA 35, n.s. 11/2, 56-62

Simpson, J.Y. 1853: Notes on some ancient Greek medical vases for containing Lykion, Monthly Journal for Medical Science 37, 24-30

Simpson, J.Y. 1855: On some ancient Greek Medical Vases for containing Lykion; and the modern use of the same drug in India, Proceedings of the Society of Antiquaries of Scotland 1, 47-54

Sjöqvist, E. 1960: Morgantina: Hellenistic medicine bottles, AJA 64/1, 78-83 
Stampolidis, N.Chr., Tassoulas, Y. (Eds) 2014: Hygieia. Health, Illness, Treatment from Homer to Galen, Athens

Stone, S.C. 2014: The Hellenistic and Roman Fine Pottery, Morgantina Studies VI, Princeton

Sztetyłło, Z. 2000: Pottery stamps, [in:] Myśliwiec, K., Sztetyłło, Z., Tell Atrib 1985-1995 I, TCAM 34, Varsovie, 53-163

Taborelli, L. 2014: Per le produzioni e i commerce del lykion nella Sicilia sud-orientale, ArchClass LXV, n.s. II, 4, 393-400

Taborelli, L. 2015: I contenitori per il Lykion di Akragas, Sicilia Antiqua 12, 87-98

Taborelli, A., Marengo, S.M. 1998: Il medicamento $\lambda$ v́кıv e i suoi contenitori, ArchClass L, 213-272

Taborelli, A., Marengo, S.M. 2010: Microcontenitori per medicamenta di epoca ellenistica e romana, ArchClass LXI, 211-242

Threatte, L. 1980: The Grammar of Attic Inscriptions I. Phonology, Berlin-New York

Vallarino, G. 2003: Un inedito contenitore di lýkion da Pompei, ArchClass LIV, n.s. 4, $351-360$

Vecchio, L. 2006: Un vaso per collirio con iscrizione greca da Velia, ParPass CCCL, 373-387

Vivliodetis, E., Giannopoulou, M. 2014: Various Medicines in Variety of Vessels, [in:] Stampolidis, N.Chr., Tassoulas, Y. (Eds), Hygieia, Health, Illness, Treatment from Homer to Galen, Athens, 50-59

Welc, F. 2014: Tell Atrib 1985-1995 IV: Faience Objects, PAM Monograph Series 5, Warsaw Youtie, L.C. 1985: P. Haun. III 47, Supplemented, BASP 22, 365-373

Zahn, R. 1904: Tongeschirr, [in:] Wiegand, Th., Schrader, H., Priene: Ergebnisse der Ausgrabungen und Untersuchungen in den Jahren 1895-1898, Berlin, 394-449

Zmeikova, I.I. 1985: Pour le commerce avec des medicaments dans l'antiquité, [in:] Lazarov, M. et al. (Eds), Thracia Pontica II. Deuxième Symposium international, Sozopol, 4-7 oct. 1982. Le littoral thrace et son rôle dans le monde ancienne, Jambol, 365-371 


\section{ÉTUDES et TRAVAUX XXX / 2017}

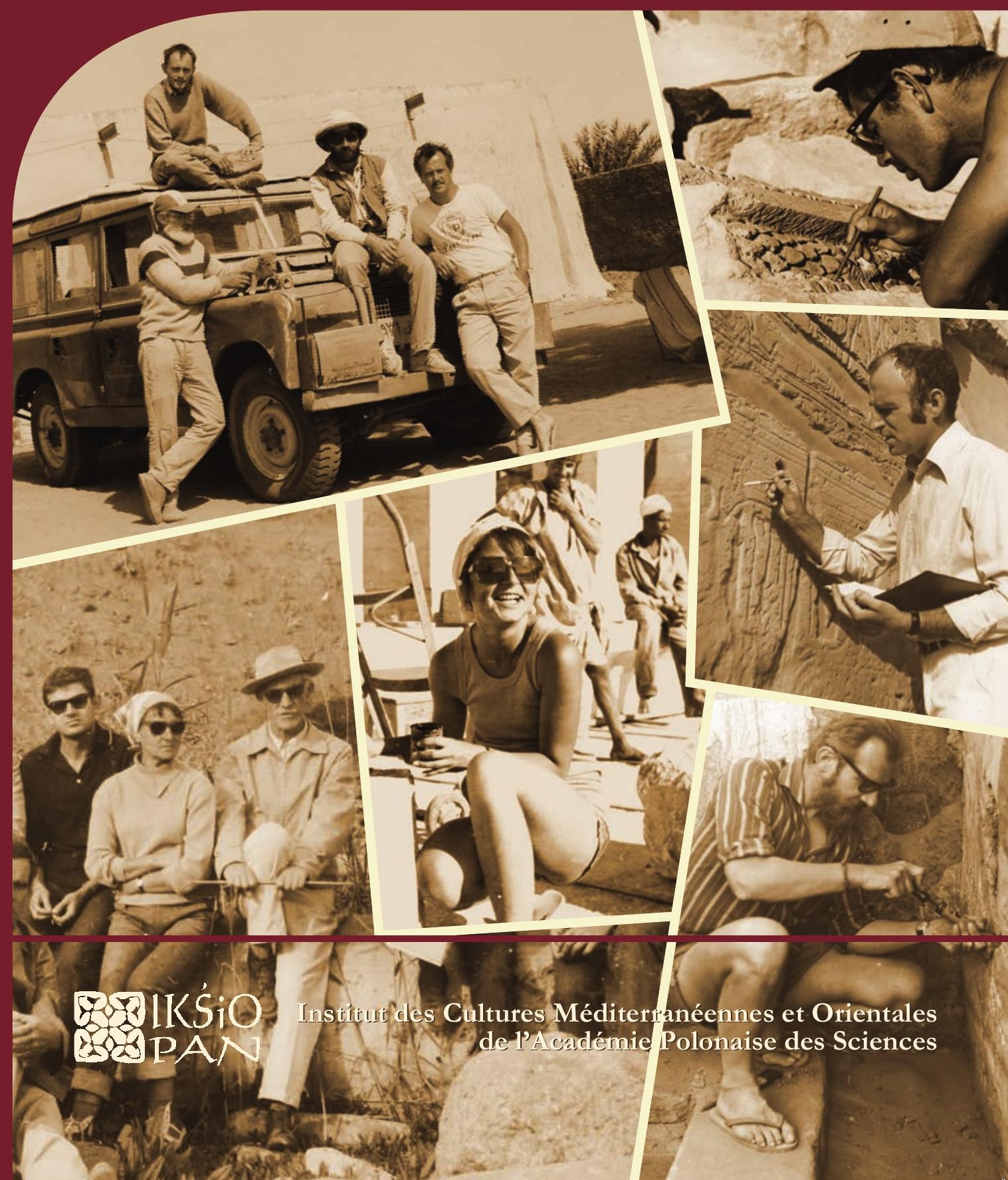




\title{
COMITÉ DE RÉDACTION SCIENTIFIQUE
}

Maciej Makowski - rédacteur en chef

Jadwiga Iwaszczuk - rédacteur et sécretaire de la rédaction

Mariusz Drzewiecki - rédacteur

Maciej G. Witkowski - rédacteur

\section{CONSEIL SCIENTIFIQUE DU JOURNAL}

M. Kobusiewicz (IAE PAS, Warszawa), E. Laskowska-Kusztal (IMOC PAS, Warszawa),

D. Michaelides (University of Cyprus, Nicosia),

J.Ch. Moretti (IRAA-MOM, Université de Lyon 2/CNRS),

D. Raue (Ägyptisches Museum der Universität Leipzig), P. Reynolds (ICREA, Barcelona),

D. Welsby (British Museum, London)

\section{COMITÉ SCIENTIFIQUE DE LECTURE}

J. Holaubek (Institut für Ägyptologie, Wien), S. Ikram (AUC, Cairo),

K. Innemée (Universiteit Leiden), J. McKenzie (Faculty of Oriental Studies, University of Oxford),

N. Strudwick (University of Cambridge), A. Loprieno-Gnirs (Universität Basel),

Ch.E. Loeben (Museen für Kulturgeschichte, Hannover), Y. Tristant (Macquarie University, Sydney),

V.W.J. van Gerven Oei (University of Aberdeen), A. Peignard-Giros (HiSoMA-MOM, Université de Lyon 2/CNRS), J.A. Ostrowski, E. Papuci-Władyka, J. Śliwa (IA JU, Kraków), R. Czerner (WUST, Wrocław), A. Ćwiek (IA AMU, Poznań), M. Wiewióra (IA NCU, Toruń), K. Domżalski

(IAE PAS, Warszawa), K.O. Kuraszkiewicz (DE FOS UW), M. Barwik, P. Bieliński, P. Dyczek, W. Godlewski, D. Ławecka, S. Rzepka, J. Żelazowski, M. Gawlikowski, J. Młynarczyk, A. Niwiński, T. Sarnowski, D. Szeląg, T. Waliszewski (IA UW, Warszawa)

\section{RÉDACTEUR THÉMATIQUE DU VOLUME \\ Barbara Lichocka}

\author{
AIDE RÉDACTION TECHNIQUE \\ Dorota Dobrzyńska, Mariusz Drzewiecki
}

REVUE DES TEXTES ANGLAIS

Jo Harper 
ÉTUDES et TRAVAUX XXX 
INSTYTUT KULTUR ŚRÓDZIEMNOMORSKICH I ORIENTALNYCH POLSKIEJ AKADEMII NAUK

\section{STUDIA i PRACE}

XXX

\section{Ro IKŚSiO \\ ESA PAN}

WARSZAWA

2017 
INSTITUT DES CULTURES MÉDITERRANÉENNES ET ORIENTALES DE L'ACADÉMIE POLONAISE DES SCIENCES

\section{ÉTUDES et TRAVAUX}

XXX

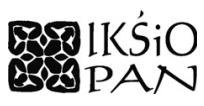

VARSOVIE

2017 
Publication scientifique financée dans le cadre du programme du Ministre de la Science et de l'Éducation Supérieure

« Programme National de Développement de l’Humanistique » pour les années 2016-2021 (projet no 3bH 150099 83)

\title{
HARODOWY PROGRAM ROZWOJU HUMANISTYKI
}

\author{
Copyright (C) \\ Instytut Kultur Śródziemnomorskich i Orientalnych PAN \\ et les Auteurs \\ Warszawa 2017
}

\author{
ISSN 2084-6762 \\ (avant $2011: 0079-3566$ ) \\ e-ISSN 2449-9579 \\ Version première en papier, imprimée en Pologne - 150 copies \\ Version électronique accessible sur \\ http://www.etudesettravaux.iksiopan.pl
}

Édition: Polskie Towarzystwo Historyczne et Wydawnictwo Neriton, Warszawa

Conception générale de couverture : J. Iwaszczuk

Photos de couverture : En haut, à gauche. Vieille Dongola 1991, S. Jakobielski

(debout à gauche), K. Pluskota (debout à droite), B. Żurawski (assis sur le camion)

et P. Wierzbicki (assis sur le camion) (de la collection de B. Żurawski)

En haut, à droite. Palmyre 1964, M. Marciniak au travail (phot. A. Dziewanowski)

Au centre. E. Laskowska-Kusztal au travail (de la collection de E. Laskowska-Kusztal)

En bas, à gauche. Tell Atrib 1962 ; de gauche : T. Biniewski, M. Marciniak, K. Kołodziejczyk,

K. Michałowski, A. Ostrasz, S. Jakobielski et S. Jasiewicz devant eux

(de la collection de IKŚSiO PAN).

En bas, à droite. Vieille Dongola 1976, S. Jakobielski nettoyant le mur (phot. M. Steinborn).

Au centre, à droite, K. Myśliwiec en train des travaux de documentation (de la collection de IKŚiO PAN) 


\section{Table des matières}

BARBARA LICHOCKA

Ergon agathon

Hartwig Altenmüller

$\mathrm{Zu}$ den Feindbildern auf den Zauberstäben des Mittleren Reiches und der Zweiten

Zwischenzeit

Nathalie Beaux

Des $m s w n s w$ de Thoutmosis III à Deir el-Bahari

Briant Bohleke, Nigel Strudwick

A Label for Opening of the Mouth Implements from the Burial of Senneferi (TT99)

and Remarks on the Ritual

Rosa Maria Bonacasa Carra, Nicola Bonacasa

Nuovi dati sugli edifici termali di Sabratha

EDWARD BROVARSKI

A Fragmentary Carrying Chair Scene in Salt Lake City, Utah

Julia Burdajewicz

Wall Painting Decoration from the North-West Church in Hippos-Sussita

of the Decapolis

Mariusz BURDAJEWICZ

From Pagan Temple to Church in Late Antiquity Palestine. A View from

Hippos-Sussita

MAREK ChlodNicki

Early Dynastic Bead Workshops at the Central Kom of Tell el-Farkha.

Patryk ChudziK, Mariusz Caban

Observations on the Architecture of the Tomb of Horhotep in Western Thebes

Krzysztof M. Cialowicz

New Discoveries at Tell el-Farkha and the Beginnings of the Egyptian State.

Amr EL-TiebI

Four Wooden New Kingdom Female Statuettes in the Egyptian Museum, Cairo 


\section{Naguib KanaWATI}

Ritual Marriage Alliances and Consolidation of Power in Middle Egypt during the Middle Kingdom

Adam Łajtar, Jolanta Mlynarczyk

A Faction Acclamation Incised on a Pithos Found Near the North-West Church at Hippos (Sussita)

Adam ŁaJTAR, Grzegorz OchaŁa

Two Private Prayers in Wall Inscriptions in the Faras Cathedral

Adam Łajtar, Anna Poludnikiewicz

Medicinal Vessels from Tell Atrib (Egypt)

JaCeK Michniewicz, Jolanta MlynarczyK

Petrographic Variability of the Fabrics of Wine Jars from Sha'ar-Ha Amakim as a Reflection of Differences in Their Provenance and Chronology

Iwona ModrzewsKa-PianetTI

Les importations d'amphores Dressel 20 en Gaule Cisalpine

Arthur SEgal

Samaria-Sebaste. Portrait of a polis in the Heart of Samaria 409

JOACHIM ŚLIWA

The Motif of a 'Blind Harper' in an Unexpected Place

MONIKA WIĘCH

Searching for the Kitchen in the Early Roman Phase of the 'Hellenistic' House at Nea Paphos (Cyprus)

Abréviations 
THE VOLUME IS PUBLISHED TO CELEBRATE

THE $60^{\text {TH }}$ ANNIVERSARY

OF THE ESTABLISHMENT OF

THE RESEARCH CENTRE FOR MEDITERRANEAN ARCHAEOLOGY POLISH ACADEMY OF SCIENCES

FOUNDED IN 1956

WHOSE MISSION IS CONTINUED BY

THE INSTITUTE OF MEDITERRANEAN AND ORIENTAL CULTURES

OF THE POLISH ACADEMY OF SCIENCES 